\title{
Viral Inclusions Present
}

National Cancer Institute

\section{Source}

National Cancer Institute. Viral Inclusions Present. NCI Thesaurus. Code C82939.

A morphologic finding indicating the presence of nuclear or cytoplasmic viral inclusion bodies. 